\title{
Beyond the Household: Marriage, Household Formation and the Role of Kin and Neighbours
}

\author{
RICHARD WALL
}

\section{INTRODUCTION}

Autobiographies and diaries have furnished many historians, including those who otherwise eschew qualitative data, with an apposite quote with which to launch their papers. Other historians select extracts from such sources to add colour to arguments advanced initially from the analysis of parish registers or court records. As a major source in their own right, diaries, autobiographies and letters provide the historian with valuable insights into the motivations, conscious or unconscious, of the authors. ${ }^{.}$Such sources are less forthcoming on the perspectives and motivations of other persons whose activities feature in the written record as their motivations have to be teased out from the distorted and necessarily partial account of the author. Nor is it always easy to distinguish exceptional events in the life of a diarist from those which might have been experienced by persons of equivalent status or even more widely. The temptation is to overgeneralize on the basis of limited evidence.

Steven King in "Chance Encounters? Paths to Household Formation in Early Modern England", has chosen to be particularly ambitious, selecting a limited number of diaries and autobiographies to challenge the applicability of the widely held association between the accumulation of economic resources and age at marriage and the claim that couples in deciding to marry assessed the state of their current resources and their future prospects. From this base Dr King launches a further set of hypotheses concerning the involvement of parents in the choice of their child's marriage partner, changes over time in the density and quality of contacts between kin and with neighbours, and the significance of these factors for the decline in the mean age at marriage in England over the course of the eighteenth century. In arguing in this way, Steven King has neglected the key strength of his sources: the setting of a particular individual in a particular social context, in favour of commenting on a general change in marriage patterns which his evidence can neither confirm nor refute. Indeed he could as well have advanced his hypotheses without citing a single diary or autobiography.

Yet there is evidence, both of a quantitative and qualitative nature, which can substantiate some of his hypotheses and modify, elaborate and challenge others. Much of this evidence has been publicly available for some consider- 
able time, but as Dr King has ignored it a brief resumé will be presented here. Not all his hypotheses can be examined due to constraints of space and in some cases the absence of appropriate data. Instead, five key issues will be examined in turn: the extent of parental support to young couples on and after marriage, the economic rationale underlying the decision to marry, the residential proximity of parents and married children, the extent of migration in London in the seventeenth and nineteenth centuries, and the nature of the financial and social assistance which poor people could expect to receive from their relations and neighbours. Inevitably some interesting issues have been left unexplored or only commented on obliquely, as in the case of trends in age at marriage, the disappearance over the course of the eighteenth century of the group of late marrying women and the appearance of earlier marrying women. The evidence that will be produced comes from a variety of time periods and places. Most of the data relate to England but, as Steven King has used some studies of populations in other parts of Europe to challenge model links between economic factors and age at marriage advanced on the basis of English evidence, the opportunity will be taken where practical to refer to the wider European context.

\section{PARENTAL SUPPORT OF YOUNG MARRIED COUPLES}

The first issue to be examined is the degree of financial support which young couples received from their parents. Such support is documented in the life histories which accompanied the time budgets which Frederick Le Play and his followers assembled from the I840s through to 1900 for particular families of peasants, artisans, tenant farmers and labourers in different parts of Europe and occasionally beyond (see Table $\mathrm{I}$ ). ${ }^{2}$ Examination of Table I reveals that more than half of the young couples received substantial financial support from their parents or parents-in-law either at the time of their marriage or later even though no account was taken of whether the parents not recorded as supporting their children had already died. Substantial support has been defined for this purpose as support of such a nature that it had a material effect, short or long term, on the family's standard of living. The purpose to which that support was put (whether invested in a business or dissipated in the nearest alehouse) was disregarded.

Measured in this way, instances of parental support can be documented for couples from northern and western Europe as well as from eastern and southern Europe. In most cases, and particularly in western and northern Europe, this support was received without the necessity for parents and adult children to co-reside. There is also evidence of regional variation with parental support received less frequently in England, the Low Countries,

2. My first analysis of these budgets was included in the introduction to Richard Wall, Jean Robin and Peter Laslett (eds), Family Forms in Historic Europe (Cambridge, 1983), pp. I8-34. 
Table I. Young married couples in the middle and later nineteenth century: crisis finance by country of residence

Support on marriage or later from

\begin{tabular}{lrrrrrrr} 
Location & Total & $\begin{array}{c}\text { Own } \\
\text { resources } \\
\text { on marriage }\end{array}$ & $\begin{array}{c}\text { Parents of } \\
\text { husband or } \\
\text { wife }\end{array}$ & $\begin{array}{c}\text { Other } \\
\text { relative }\end{array}$ & Employer Other \\
\hline England & 7 & 7 & 3 & 1 & 0 & 1 \\
Netherlands & 2 & 2 & 1 & 0 & 1 & 2 \\
Belgium & 8 & 5 & 4 & 1 & 2 & 2 \\
France, north & 31 & 14 & 21 & 1 & 9 & 5 \\
France, Paris & 20 & 15 & 8 & 9 & 3 & 6 \\
France, south & 19 & 10 & 16 & 5 & 3 & 2 \\
Spain & 3 & 3 & 0 & 0 & 1 & 2 \\
Italy & 9 & 5 & 6 & 3 & 2 & 3 \\
Scandinavia & 3 & 0 & 1 & 0 & 2 & 1 \\
Switzerland & 3 & 2 & 1 & 0 & 0 & 0 \\
Germany & 6 & 4 & 3 & 1 & 4 & 1 \\
Eastern Europe & 5 & 1 & 3 & 0 & 3 & 2 \\
USSR & 7 & 2 & 7 & 4 & 6 & 2 \\
North Africa & 3 & 2 & 2 & 1 & 0 & 0 \\
Syria & 1 & 0 & 1 & 1 & 0 & 0 \\
Reunion Is. & 1 & 1 & 0 & 0 & 1 & 0 \\
China \& Cambodia & 2 & 1 & 1 & 0 & 0 & 1 \\
Canada \& USA & 2 & 1 & 1 & 0 & 0 & 0 \\
Total & 132 & 75 & 79 & 27 & 37 & 30 \\
\hline
\end{tabular}

Note: The categories are not mutually exclusive.

Sources: Richard Wall, "Introduction", in Richard Wall, Jean Robin and Peter Laslett (eds), Family Forms in Historic Europe (Cambridge, 1983), p. 24, based on analyses of family monographs collected by Le Play and his followers, Ouvriers des deux mondes, Ist series, vols I-5, 2nd series, vols I-5 (I857-1899); F. Le Play, Les ouvriers Européens: études sur les travaux, la vie domestique, et la condition morale des populations ouvrières de l'Europe (Ist ed., Paris, I855; 2nd ed., vols II, IV, V, Tours, I875-1879).

Spain, Germany, Switzerland and Paris than in other parts of Europe. Underlying these variations were differences in the nature of the local economy. Couples who were peasants or smallholders were much more likely to receive financial support from their parents than were couples who were factory workers or labourers (Table 2). Such differences reflect the poverty of the latter's parents and the nature of their assets more than their exposure to a higher level of mortality as the differences in the frequency of assistance from parents exceed what could be expected given the variations in mortality rates across Europe. ${ }^{3}$

3. For an overview of differences in life expectancy between a number of European countries in the nineteenth century, see Graziella Caselli, "L'évolution à long terme de la mortalité en Europe", in Alain Blum and Jean-Louis Rallu (eds), European Population, vol. 2 (Paris, I993), p. II4. 
Table 2. Young married couples in the middle and later nineteenth century: crisis finance by social position

\begin{tabular}{lcccc}
\hline $\begin{array}{l}\text { Source of support } \\
\text { marriage or later }\end{array}$ & \multicolumn{4}{c}{ Social position of couple } \\
& Peasant & Smallholder $^{3}$ & Factory worker $^{4}$ & Labourer \\
\hline Own resources on marriage & 6 & 7 & 5 & 5 \\
Parents of husband or wife & 16 & 8 & 5 & 2 \\
Other relative & 7 & 1 & 1 & 2 \\
Employer & 0 & 2 & 6 & 1 \\
Non-relative & 2 & 2 & 2 & 4 \\
Total & 17 & 10 & 11 & 7 \\
\hline
\end{tabular}

Notes:

I. The categories are not mutually exclusive.

2. Defined on the basis of the husband's occupation.

3. Includes market gardeners.

4. Includes smelters.

Sources: Wall, "Introduction”, p. 27, based on analysis of family monographs by Le Play and his followers.

\section{THE ECONOMIC RATIONALE FOR MARRIAGE}

It is evident, therefore, that parental support of the newly married couple was important for their future well-being and this might have influenced their decision as to whether to marry and the timing of that marriage. Table I also shows, however, that almost as many couples had accumulated resources of their own prior to their marriage as would be supported by their parents. English couples were particularly likely to meet at least part of the cost of their new home from their own resources. This also seems to have been the case for the majority of couples from the Low Countries, Germany, Switzerland and Paris. Viewed in relation to the social position of the couple (see Table 2), it appears that the children of labourers and smallholders were the most likely and the children of peasants least likely to depend in part on their own resources.

The significance of the substantial support originating with the couple themselves is the implication it carries that changes in economic circumstances which affected or threatened the couple could in certain circumstances delay their marriage or in extreme circumstances lead to its abandonment regardless of any assistance that might be forthcoming from the parents. Establishing parental involvement in the marriage process as Dr King has done in no way invalidates associations between variations in economic circumstances and the timing of marriages. Indeed, there is any amount of evidence to indicate that the number of marriages celebrated rose and fell with expansion and contractions of the economy. ${ }^{4}$ The more

4. See for example D.V. Glass, "Marriage Frequency and Economic Fluctuations in England and Wales, I851 to 1934", in Lancelot Hogben (ed.), Political Arithmetic. A Symposium of Population Studies (London, 1938), p. 257. 
interesting question, not posed by Dr King, is what circumstances first gave rise to the pattern of a mean age at marriage of the mid or late twenties which was typical for both sexes in large parts of Europe in the past. ${ }^{5}$

An issue which Steven King does raise is why women should have chosen to marry partners without resources and whose economic prospects were uncertain. He challenges the argument of Bridget Hill that women married because they had no choice, thus conflating the decision to marry with the decision to marry a particular individual. ${ }^{6}$ In fact, as Table 3 makes clear, the economic prospects were dismal for a woman from the wage-earning class who did not marry or on widowhood did not remarry. This analysis derived from analysis of the census of Corfe Castle, Dorset, in 1790 indicates that the weekly income of a single woman in her late thirties or early forties was no more than 16 pence, considerably less than the 27 pence of a married woman of this age. Younger widows were in an even worse situation with incomes on average less than half those of married women. For older single women (aged 55-64) the disparities were even greater. Their incomes were less than a third of those of married women of a similar age. When the Poor Law intervened as it did in the case of widows and older single women such disparities could be substantially reduced although not obliterated. Women from these social groups had a powerful economic incentive to marry even though embodied in these calculations is an appreciation that the resources of the household were not distributed equally between husband and wife, but that the former would consume a further half share of the resources of the household above that available to his wife. ${ }^{7}$ Establishing that these women would be considerably poorer if they did not marry does not of course prove that it was this factor and this factor alone that informed their attitudes towards marriage. As the sample diaries and autobiographies chosen by Steven King document, some marriages were planned by the parental generation and some were not, some parents were tyrannical and some children were wilful and this helped occasion a wide spread of marriage ages around the mean.

5. An issue explored by Michael Mitterauer in "Medieval Roots of European Family Development" (unpublished proceedings of the conference "Where Does Europe End?", Budapest, 1994). There is a copy of this paper in the Library of the Cambridge Group and a brief resumé in Richard Wall, "Characteristics of European Family and Household Systems", in Francisco Chacón Jiménez and Llorenc Ferrer I Alás (eds), Familia, Casa y Trabajo (Murcia, 1997), p. 22. Mitterauer has argued that the north-west European household system of late mean ages at first marriage and the predominance of simple family households was established in the early Middle Ages, influenced by the beliefs and administrative practices of the western Church, in conjunction with tighter control over access to land following a deteriorating land-labour ratio.

6. B. Hill, "The Marriage Age of Women and the Demographers", History Workshop Journal, 22 (1989), as cited by Steven King in "Chance Encounters".

7. The assumptions on which these calculations of income are based are set out in greater detail in Richard Wall, "Some Implications of the Earnings, Income and Expenditure Patterns of Married Women in Populations in the Past", in John Henderson and Richard Wall (eds), Poor Women and Children in the European Past (London and New York, 1994), p. 332, note 16. 
Table 3. Median weekly income of wage-earning women in Corfe Castle, Dorset, in 1790

\begin{tabular}{lcccc}
\hline Age group & \multicolumn{3}{c}{ Median income in pence } \\
& & Single & Married & Widowed \\
\hline $35-44$ & No poor relief & 16 & 27 & 12 \\
& With poor relief $^{2}$ & 16 & 28 & 24 \\
$55-64$ & No poor relief & 12 & 43 & 27 \\
& With poor relief $^{2}$ & 36 & 43 & 31 \\
Numbers & 35-44 & 4 & 21 & 5 \\
& $55-64$ & 3 & 15 & 7 \\
\hline
\end{tabular}

Notes:

I. Assuming that the husband (where present) consumed half as much again of the resources of the household as his wife, and a son aged $\mathrm{I} 5+$ a quarter as much again; for a full account of the assumptions see Richard Wall, "Some Implications of the Earnings, Income and Expenditure Patterns of Married Women in Populations in the Past", in John Henderson and Richard Wall (eds), Poor Women and Children in the European Past (London and New York, 1994), p. 332, n. I6.

2. Assuming a contribution from the Poor Law of two shillings per week to each woman in receipt of relief.

Source: Calculated from Census of Corfe Castle 1790, included in J. Hutchins, The History and Antiquities of the County of Dorset, eds R. Gough and J. Nichols (London, I796-I8I5), vol. I, pp. xc-xciii.

In addition, some of the most important assets of these young men, namely their youth, strength, work experience and skill have been overlooked in Dr King's account of marriage patterns. It is perhaps natural that a personal record such as a diary or autobiography should dwell on personal relationships and omit reference to the writer's own apparently more mundane attributes, but these other factors were also important in bringing a courtship to a successful conclusion. Admittedly, many of these inhabitants were very poor and their job security minimal, but their strength, resolve and the ability to acquire a variety of skills would have served them well in the flexible economy of early modern England and been appreciated by their prospective partners. In some societies in the past large numbers of women eschewed formal marriage and entered into a variety of informal relationships with men. Stockholm in the early nineteenth century furnishes one such example, and Vienna another. ${ }^{8}$ In these cases the work available to the men these women might have expected to marry was so irregular and/ or poorly paid that women received no economic advantage from marriage. Similarly, whenever women were relatively well paid for their work, the economic incentive for them to marry was reduced.

8. On Stockholm see Margareta R. Matovic, "The Stockholm Marriage: Extra-Legal Family Formation in Stockholm I860-I890", Continuity and Change, I:3 (1986), pp. 385-413. 
Table 4. Residential propinquity of parents and married children: England, eighteenth to twentieth centuries

\begin{tabular}{|c|c|c|c|c|c|c|c|}
\hline \multirow[t]{3}{*}{ Place } & \multirow[t]{3}{*}{ Date } & \multicolumn{6}{|c|}{$\begin{array}{l}\text { Percentage }^{1} \text { of married sons and daughters resident in } \\
\text { same parish or within } 5 \text { miles of parent }(s)\end{array}$} \\
\hline & & \multicolumn{2}{|c|}{ Married sons } & \multicolumn{2}{|c|}{ Married daughters } & \multicolumn{2}{|c|}{ Nos. } \\
\hline & & $\begin{array}{c}\text { Same } \\
\text { parish }^{2}\end{array}$ & $\begin{array}{l}\text { Under } \\
5 \text { miles }^{3}\end{array}$ & $\begin{array}{l}\text { Same } \\
\text { parish }^{2}\end{array}$ & $\begin{array}{c}\text { Under } \\
5 \text { miles }^{3}\end{array}$ & Sons & Daughters \\
\hline Cardington, Beds & 1782 & 26 & 49 & 22 & 57 & 38 & 40 \\
\hline Stoke Poges, Bucks & 1831 & 46 & - & 34 & - & 26 & 38 \\
\hline Caunton, Notts & 1846 & 48 & 66 & 30 & 60 & 45 & 47 \\
\hline England & 1951 & 30 & 47 & 32 & 49 & 283 & 289 \\
\hline Swansea, Glamorgan & 1960 & 26 & 71 & 42 & 85 & 383 & 408 \\
\hline Northern farmers & c. 1960 & 63 & - & 37 & - & 35 & 81 \\
\hline Five Towns & $1983^{4}$ & 18 & 34 & 25 & 40 & 408 & 436 \\
\hline
\end{tabular}

Notes:

I. Percentages are cumulative. Missing data are indicated by dashes.

2. Within $2 \mathrm{~km}$ (I.24 miles) for England (I95I) and Five Towns (I983); same locality for Swansea (1960).

3. Within $5 \mathrm{~km}$ (3 miles) for England (195I) and Five Towns (1983); other part of the municipality for Swansea (1960).

4. Married children co-residing with parents were excluded and the percentages given in the table are therefore slight understatements of the percentages resident in the same parish or within 5 miles of their parents.

Source: Richard Wall, "Relationships Between the Generations in British Families Past and Present", in Catherine Marsh and Sara Arber (eds), Families and Households: Divisions and Change (Basingstoke, 1992), p. 73.

\section{RESIDENTIAL PROXIMITY OF PARENTS AND MARRIED CHILDREN}

In terms of the social support parents might render their children (and vice versa), one critical factor was the geographical distance that separated them. Some evidence on this point is marshalled in Table 4 for a variety of English (and one Welsh) populations at various dates between the late eighteenth and late twentieth centuries. Married sons and daughters are considered separately because of the very different type of support each might provide (and need). Distance is measured in terms of residence in the same parish (and hence offering most parents the opportunity of frequent daily contact with their children particularly in the case of one settlement parish), or within five miles (eight kilometres) of each other when contact would have been relatively easy but less likely to occur by chance. In his article Dr King is inclined to the view that kin networks were particularly dense in some populations, possibly becoming more dense over time with the expansion of proto-industry, mining and competition for rural labour in northern England. 
Examination of Table 4 shows that there were such communities, but that they were at least as likely (perhaps more likely) to occur in the midtwentieth century than a century or more earlier. Thus the largest concentration of married sons within the same parish as their parents was recorded for a group of northern farmers in 1960 while the largest concentration of married daughters within the same locality as their parents was registered for Swansea also in 1960. The earliest parish to be enumerated, Cardington in 1782 , yielded some of the lowest rates of residential proximity. Under a quarter of the sons and daughters who had married resided in Cardington like their parents, and just half of the sons, and 57 per cent of the daughters were within five miles of Cardington. However, Cardington was on the main road between Bedford and London (and adjacent to Bedford) and there was a shortage of employment opportunities for young males. Caunton and Stoke Poges with close to half of the married sons and a third of the married daughters still resident in the parental parish may be more representative of the experience of rural England in the early nineteenth century. In these parishes higher proportions of married children lived close to their parents than was generally the case in England in 195I, but the differences were not particularly marked (for example just under half of married sons and daughters resident within three miles of their parents in I95I compared with approximately two-thirds resident within five miles of their parents in the case of Caunton and Stoke Poges).

Just how the pattern of residential proximity between parent and married child might have evolved over the course of time is, therefore, as yet uncertain. What can be stated is that the varying proportions of married sons and daughters from the three rural parishes enumerated before 1850 and who were resident within the same parish or within five miles of their parents are in general accord with what is known about migration patterns over the life course, with most mobility confined within a radius of ten miles of the birthplace. ${ }^{\text {IO }}$

\section{THE MOBILITY OF LONDONERS}

Table 4 has identified some towns from the twentieth century with substantial numbers of married children residing close to their parents. As towns expanded in the nineteenth century, similarly dense or denser networks may

9. Higher rates of residential proximity are suggested if instead of calculating the proportion of children resident within a given distance of their parents, the calculation shows the proportion of parents within a given distance of the nearest married child. These latter calculations appear in Richard Wall, "Relationships Between the Generations in British Families Past and Present", in Catherine Marsh and Sara Arber (eds), Families and Households. Divisions and Change (Basingstoke, 1992), pp. 74-75.

Io. See for example Bessie Maltby, "Parish Registers and the Problem of Mobility", Local Population Studies, 6 (197I), p. 4I. 
Table 5. Residential mobility of the working class: the inhabitants of the parish of St George in the East, London, in 1845

\begin{tabular}{lcc}
\hline Time in current dwelling & $\mathrm{N}$ & Percentage \\
\hline Less than 4 weeks & 65 & 3 \\
$1-6$ months & 391 & 20 \\
6 months-1 year & 300 & 15 \\
1-3 years & 497 & 25 \\
Over 3 years & 701 & 36 \\
Total & 1,954 & 100 \\
\hline
\end{tabular}

Source: "Report of the Council of the Statistical Society of London [. . .] appointed to make an Investigation into the State of the Poorer Classes in St. George's in the East", Quarterly Journal of the Statistical Society of London (I848), p. 228, reprinted in Richard Wall (ed.), Slum Conditions in London and Dublin (Farnborough, 1974).

have been created although this may have taken a generation or two of urban residence to achieve. However, the extent of mobility in both the early modern and nineteenth-century town was such that it must be doubtful whether the characters of young people would be known to their prospective partners (and their parents) in the way predicted by Steven King. For example, the survey of the working-class population of the east London parish of St George in the East in I846 established that 3 per cent of the households had resided in their current dwelling for less than a month. ${ }^{\text {II }}$ Nearly four out of ten had moved in within the previous year and only just over a third had lived there for more than three years (see Table 5). Most had probably not moved far, but they had moved and could establish their reputations in a new environment.

A source of a different character, a Poll Tax Register of defaulters from I698 for a parish adjacent to the City of London illustrates certain aspects of the migration patterns of the residents of London at the end of the seventeenth century. This particular poll tax had to be paid quarterly and the collectors for two of the wards of the parish were particularly assiduous in trying to locate those who had moved since their names had been inscribed in the Register, presumably by making enquiries of any remaining residents at their last address or of the neighbours. There would not appear to be any other way in which this information could have been gathered. Table 6 sets out the information they were able to collect on the current location of these former residents of St Clement Danes. Given that the remaining residents might evidence a natural reluctance to disclose the current address of their late neighbours to a tax collector and land them with

II. "Report to the Council of the Statistical Society of London [...] appointed to make an Investigation into the State of the Poorer Classes in St George's in the East”, Quarterly Journal of the Statistical Society of London, XL, III (I848), p. 228, reprinted in Richard Wall (ed.), Slum Conditions in London and Dublin (Farnborough, 1974). 
Table 6. Information given to poll tax collector on destination of migrants from the parish of St Clement Danes, Westminster, I698

\begin{tabular}{lcc}
\hline Information & Holywell Ward & Sheare Lane Ward \\
\hline Proximity to local landmark $^{1}$ & 23 & 22 \\
Named court, yard or street $^{2}$ & 16 & 29 \\
Suburb of London $^{2}$ & 9 & 8 \\
Named town & 9 & 8 \\
Named county $_{\text {England and Wales }}{ }^{2}$ & 4 & 2 \\
At sea or abroad & 4 & 2 \\
Unknown $_{\text {Total }}$ & 6 & 2 \\
N & 29 & 27 \\
\hline$N$
\end{tabular}

Notes:

I. For example: Crown, Fleet Street; near Red Lion Square; Temple. Includes three instances where the householder at the new address is identified.

2. Named London suburb or city without further description.

3. Individuals identified as having "gone into the country".

Source: Corporation of London Record Office, "Estreats into Exchequer being names of persons in each parish etc., abated, poor, deceased and gone”, MS 40, p. II4.

a bill, the information provided on migration patterns must be viewed particularly carefully. The extent of the information that the collectors were able to obtain on the destination of the migrants was from one point of view minimal. A specific address was provided for only three migrants (all local movers). On the other hand, an approximate destination (town or county for most of the long-distance migrants, specific street, court, yard or proximity to a prominent landmark for local migrants) was ascertained for over 70 per cent of the migrants, implying that there had been some discussion of the intended destination of a large majority of the migrants. As close to half of the migrants whose destinations were recorded had moved out of their immediate neighbourhood to reside in another suburb, move to the country, go to sea or live abroad it is evident that there was little chance that information as to their characters as developed in St Clement Danes would travel with them.

\section{THE RESPECTIVE ROLES OF KIN AND NEIGHBOURS}

The final section of this article illustrates the nature of the practical help that an individual family of the labouring class might expect to receive either from their relatives or from their neighbours. On this occasion the regular points of contact can be measured in addition to emergency aid provided during a life course crisis (such as on marriage of a child) as discussed above in connection with Tables I and 2 above. The information has been derived from Flora Thompson's classic account of early childhood 
Table 7. Role of kin and neighbours of labouring families in Juniper Hill, Oxfordshire-Northamptonshire border, in the I880s

Neighbours Kin

\section{Cooperation}

1. Sleep over at neighbours whose children left home (older boys)

2. Borrowing of items for household (most women)

3. Lending of novelettes (women)

4. Tea drinkings (younger women)

5. Mutual visiting

6. Writing letters for elderly when ill and sending newspaper

7. Help with confinement, housework, cooking and washing if no daughter or other relative

Setting of standards

1. Housework: cleaning and drawing of water (women)

2. Conformity of behaviour in dress and attitude to school (children)

3. Criticism if mother pregnant at same time as daughter

Tensions

1. Locked wells during drought

2. Locked doors and closed windows to evade gossips

Explicit limitations

1. Meals never provided

2. Limited knowledge of each other's economic circumstances

3. No personal care of elderly when ill
Cooperation

1. Meals provided at festivals (married children and their families)

2. Discussion of problems (grandfather)

3. Assistance in event of confinement and with housework, cooking and washing (daughter or other relative)

Setting of standards

1. Chastisement of children (grandfather)

Source: Flora Thompson, Lark Rise to Candleford (Oxford, 1945).

during the I88os in Juniper Hill on the Oxfordshire-Northamptonshire border. ${ }^{12}$ Flora Thompson has a good deal to say about neighbours and considerably less about kin as a glance at Table 7 reveals. Yet from one point of view kin were more important than neighbours. In her poor community only relatives were offered meals. Only relatives explicitly intervened in family affairs by disciplining the children. And it was relatives, specifically female relatives, who were expected to take on the mother's household chores during her confinement.

On the other hand, the regular social contacts were with neighbours rather than with kin. The contacts were not only frequent but varied, rang-

I2. Flora Thompson, Lark Rise to Candleford (Oxford, 1945). 
ing from mutual visiting and the borrowing of small items of food to the provision of emergency accommodation (allowing older boys to sleep over) and limited help (but not nursing) to the elderly when they fell ill. The contacts were so frequent that they on occasion engendered tensions as indeed did regular contact with kin in medieval times (and perhaps later). ${ }^{13}$ Indirectly neighbours were also able to condition behaviour by adopting certain expectations of appropriate behaviour which it was almost impossible for the individual to break. The important points to note are that the relationships were not always harmonious, and that the nature of the contacts although frequent avoided the creation of burdensome and expensive ties of obligation in that meals were never provided nor would neighbours undertake the personal care of the ill and elderly.

\section{CONCLUSION}

There are a considerable number of issues raised by Dr King's study which it has not been possible to cover in this article. For example there is the whole question of the survivorhood of parents to the time of marriage of their children and the numbers of other types of relative with whom individuals at particular ages could interact (when within easy reach). Fortunately the extent of the kin network within contrasting demographic regimes has been thoroughly investigated elsewhere. ${ }^{14}$ Nor has it been possible on this occasion to mention the complementary nature of the assistance which the needy received from the family, charity and the Poor Law. This, too, has been documented elsewhere. ${ }^{15}$

The major findings of the present study have been first to emphasize that the receipt of significant financial assistance from the parental generation did not preclude the couple contributing to the establishment and maintenance of their new household from their own resources. It is possible, therefore, for age at marriage to vary in line with economic conditions even though some transfer of resources from parent to child was likely at, or shortly after, the child's marriage. Second, it has been possible to indicate the dire economic consequences faced by those women from the wage-earning class who did not marry in circumstances when the men they might marry had a variety of employment options and the wage differential between men and women was high. Third, evidence has been produced to demonstrate that not all communities in the English past embodied concentrations of close kin. London in particular was a highly mobile society offering little chance that knowledge

I3. See R.M. Smith, "Kin and Neighbors in a Thirteenth-Century Suffolk Community", Journal of Family History, 4:3 (1979), pp. 219-256.

I4. Peter Laslett, "La parenté en chiffres", Annales: Economies, Sociétés, Civilisations (1988), pp. 5-24.

I5. Wall, "Relationships Between the Generations", pp. 79-84. 
of the reputations of many of its inhabitants would be preserved with it. Finally, some suggestions were volunteered as to the limitations on the ability of kin and more particularly neighbours to influence the lives of other residents of the community. 